\title{
RELATION BETWEEN LEARNING STYLES, METHODS FOR OBTAINING INFORMATION AND ACADEMIC ACHIEVEMENTS OF TURKISH UNIVERSITY STUDENTS
}

\author{
Gülay YILMAZEL ${ }^{1}$ \\ Nuriye BÜYÜKKAYACI DUMAN \\ Ayşe Burcu BAŞÇI $I^{3}$
}

Citation/OO: Yılmazel, Gülay; Büyükkayacı Duman, Nuriye; Başç, Ayşe Burcu, (2015). Relation Between Learning Styles, Methods For Obtaining Information and Academic Achievements of Turkish University Students, Hitit University Journal of Social Sciences Institute, Year 8, Issue 1, June 2015, pp. 225-233

Abstract: The aim of this descriptive study is to determine relation between learning styles, learning methods and academic achievement of university students. This study was conducted in 2014 and the sample was consisted of 130 university students training in second and forth levels from School of Health. We used Turkish version of VARK scale for determining learning styles. In this study, 60.0\% of the students were using of multimodal and $40.0 \%$ were using unimodal learning styles. The kinesthetic modal was the most preferred among the unimodal learning styles. We found that the usage of visual and auditory learning styles was very low despite the content of nursing education programs. Nursing programs necessitate skills on problem solving in clinical education from first to fourth years which were based on patient education, treatment and care. Therefore academicians in nursing schools should encourage to students using active learning styles.

Keywords: University Students, VARK Learning Styles, Academic Achievement.

Makale Geliş Tarihi: 09.09.2014/ Makale Kabul Tarihi: 10. 06. 2015

1 Yrd. Doç. Dr., Hitit Üniversitesi Sağlık Yüksek Okulu, e-posta: dryilmazelgul@gmail.com

2 Yrd. Doç. Dr., Hitit Üniversitesi Sağlık Yüksek Okulu e-posta: nuriyebuyukkayaci@hitit.edu.tr.

3 Arş. Gör., Hitit Üniversitesi SağlıkYüksek Okulu e-posta: aburcuakbulut@hitit.edu.tr 


\section{Türk Üniversite Öğrencilerinin Öğrenme Stilleri, Bilgiyi Edinme Yöntemleri ve Akademik Başarıları Arasındaki İlişki}

Atıf/O: Yılmazel, Gülay; Büyükkayacı Duman, Nuriye; Başç, Ayşe Burcu, (2015). Türk Üniversite Öğrencilerinin Öğrenme Stilleri, Bilgiyi Edinme Yöntemleri ve Akademik Başarıları Arasındaki İlişki, Hitit Üniversitesi Sosyal Bilimler Enstitüsü Dergisi, Yıl 8, Sayı 1, Haziran 2015, ss. 225-233

Özet: Tanımlayıcı tipteki bu çalışmanın amacı üniversite öğrencilerinin öğrenme stilleri, bilgiyi edinme yöntemleri ve akademik başarıları arasındaki ilişsinin belirlenmesidir. Araştırmanin örneklemi 2014 yılında Hitit Üniversitesi Sağlık Yüksekokulu'nun ikinci ve dördüncü sinıf düzeyinde lisans eğitimi alan 130 öğrenci ile oluşturuldu. Öğrenme stillerinin belirlenmesinde VARK ölçeğinin Türkçe versiyonu kullanıldı. Öğrencilerin \%60.0'ı çoklu, \%40.0'ı tekli öğrenme stilini kullanıyordu. Tekli öğrenme stilleri arasında kinestetik model en çok tercih edilen öğrenme stili idi. Görsel ve işitsel ögrrenme stillerinin kullanımı hemşirelik programının içeriğine rağmen düşük bulundu. Hasta eğitimi, tedavisi ve bakımı üzerine temellendirilen hemşirelik programları birinci sinıftan dördüncü sinıfa kadar olan klinik eğitimde problem çözme becerilerini içerir. Bu nedenle hemşire yetiştiren akademisyenler öğrencileri aktif ögrenme stillerini kullanma yönünde teşvik etmelidir.

Anahtar Kelimeler: Üniversite Öğrencileri, VARK Öğrenme Stilleri, Akademik Başarı.

\section{INTRODUCTION}

In recent years, with the increase of technological facilities, a changing trend is seen from student-centered education to teacher-centered, from pedagogical training to andragogical in all levels of education. This trends can contribute positively on personal development and academic achievement of nursing students in under graduate-level education (Collins, 2004:1484) The term, 'learning style' describes an individual's preferred method of gathering, processing, interpreting, organizing and analyzing information (Kharb et al, 2013:1090).

Fleming and Miles defined four sensory modalities of learning: visual, auditory, read-write, and kinesthetic. Visual learners prefer the use of diagrams and symbolic devices such as graphs, flow charts, hierarchies, models, and arrows that represent printed information. Read-write learners prefer printed words and texts as means of information intake; they also prefer lists, glossaries, textbooks, lecture notes, or handouts. Auditory learners prefer "heard" information and, thus, enjoy discussions, lectures, and tutorials whilst 
acquiring new information. Kinesthetic learning is a multimodal measurement employing a combination of sensory functions. Kinesthetic learners have to feel or live the experience to learn; they prefer simulations of real practices and experiences, field trips, exhibits, samples, photographs, case studies, "real-life examples," role-plays, and applications to help them understand principles and advanced concepts. Some learners have a preference for one of these learning modalities, whereas multimodal learners do not have a strong preference for any single method. They rather learn via two or more of the modalities (Fleming \& Mills, 1992:140).

Learning styles are personal qualities that influence the way students interact with their learning environment, peers, and teachers (Alkhasaweh et al, 2008:572) It is reported to be an important factor in learning which varies from individual to individual (Tuysuz \& Tatar, 2008: 98). Learning styles can be useful to measure appropriate learning methods to improve learning for students (Nuzhat et al, 2011: 71). Learners' abilities to use different methods of learning depends on being aware of their learning styles (Arsal \& Ozen, 2007:152; Okur et al, 2011:125). Today, developments in the health care systems made necessary that giving nursing education in framework of a holistic approach by evidence-based care. Students' adaptation to innovations and developments and their success in nursing education depend on using effective learning styles and methods.

The aim of this study is to determine relation between learning styles, learning methods and academic achievements of university students.

\section{MATERIALS \& METHODS}

This descriptive study was conducted in Hitit University Health School in 2014. Study was planned according to Helsinki Principles. Participants of study was consisted of 140 nursing students training in second and forth level of their education. Without sample selection we administered a 27 item question form to 130 students who were participated to study voluntarily. Achievement rate was $92.8 \%$. In the question form we asked socio-demographic features, methods for obtaining information and Turkish version of VARK scale (Fleming, 2007:1). Each question aimed to place respondents in a "learning" situation. The respondents were permitted to omit a question or to choose two or more options if appropriate. Questionnaires were evaluated on the basis of previously validated scoring instructions and a chart. Students' general academic average grades were obtained from faculty advisers. The data was evaluated in SPSS statistic programme. In analysis percentages, means, Kruskal Wallis Ki-Kare and Chi-square test were used. 


\section{RESULTS}

The $70.0 \%$ of the students were female, $30.0 \%$ were male. $53.1 \%$ of were aged 21 and over. The mean age was $20.70 \pm 1.70$. The $56.9 \%$ of were in the second grade, $43.1 \%$ were in the fourth grade. Students' academic achievement average was $2.59 \pm 0.53$.

Learning styles among university students were shown in Graphic 1. Considering learning styles of nursing students it was determined that there are $40.0 \%$ of unimodal, $60.0 \%$ of multimodal learners in the group.

Unimodal and multimodal learning styles among university students were shown in Graphic 2. 26.9\% of those who prefer unimodal learning styles were kinesthetic, 6.9\% were visual, 3.1\% were read-write and the auditory learners. In the multimodal group it was found that $34.6 \%$ were bimodal, $17.7 \%$ were tri-modal and $7.7 \%$ were quad-modal learners.

Learning styles according to some features of university students were given in Table 1. The average age of students was lower in auditory learners than the others. Although there was no significant difference between learning styles and age means. Female students were using all learning styles on the contrary male students. $53.8 \%$ of female and $74.4 \%$ of male were using multimodal learning styles. Students using multimodal learning styles had higher academic achievement.

Methods to obtain information according to the learning styles in university students were shown in Table 2. Among the students using their own notes $27.7 \%$ were kinesthetic, $58.0 \%$ were multimodal learners. $60.3 \%$ of the students who use other people's lecture notes and $71.0 \%$ of the students who do not only consult only Turkish books and literature were multimodal learners. $(\mathrm{p}<0.05)$.

\section{DISCUSSION}

Knowledge of learning styles is considerably valuable that may help educators identify and solve learning problems among students, thus helping their students to become more effective learners (Baykan \& Nacar, 2007:159; Shah et al, 2011:229). In this study, two-thirds of the students was determined as user of multimodal learning styles (Graphic 1). In fact in many studies it has been shown that using multimodal learning styles among university students varies between the rate of $58-64 \%$. The results obtained from this study have been determined consistent with the results of other studies (Kharb et al, 
2013:1091; Baykan \& Nacar, 2007:159; Shah et al, 2011:228). On account of conditions from education system can format the students' learning styles and can contribute to use many combination learning styles during the years from primary school to university.

The kinesthetic modal was the most preferred $(27.7 \%)$ among the unimodal learning styles (Graphic 2). Indeed, in other studies similar results were obtained. It was reported that kinesthetic learners change and embody information through experiences, discussions and direct association (Shah et al, 2011:228; Johnson, 2009:3). In the present study there were no significant differences between students' learning styles according to their ages, gender, grade levels and academic achievement scores (Table 1). On the other hand, a study showed significant differences between learning styles according to grade levels (Baykan \& Nacar, 2007:160). It was determined that kinesthetic and multimodal learners were significantly using others' lecture notes and this learners were not only settling for Turkish books and literature for obtaining information (Table 2). Kinesthetic and multimodal students prefer information to arrive in a variety of modes. These students apply to different methods for achieving meaningful success (Cortright et al, 2005:109; Lujan \& Dicarlo, 2006:19).

\section{CONCLUSIONS}

In conclusion, we found that the usage of visual and auditory learning styles was very low despite the content of the nursing education programs. Conversely it was found very satisfactory for the active learning that the rate of multimodal learners was $60.0 \%$. Nursing programs necessiate skills on problem solving in clinical education from first to fourth years which were based on patient education, treatment and care. Therefore health educators should encourage students using active learning styles. 


\section{REFERENCES}

ALKHASAWEH, I.M., Mrayyan, M.T., Docherty, C., Alashram, S., Yosef, H. (2008). Problem-Based Learning (PBL): Assessing Students' Learning Preferences Using VARK. Nurse Education Today, 28, 572-579.

ARSAL, Z.,\& Ozen, R. (2007). Examining the Learning Strategies and Learning Style Preferences of Candidate Classroom Teachers. Journal of Abant Izzet Baysal University Faculty of Education, 7 (2), 151-164.

BAYKAN, Z., \& Nacar M. (2007). Learning Styles of First-Year Medical Students Attending Erciyes University in Kayseri, Turkey. Adv Physiol Educ, 31, 158-160.

COLLINS, J. (2004). Education Techniques for Lifelong Learning: Principles of Adult Learning. Radiographics, 24(5), 1483-1489.

CORTRIGHT, R.N., Collins, H.L., DiCarlo, S.E. (2005). Peer Instruction Enhanced Meaningful Learning: Ability to Solve Novel Problems. Adv Physiol Educ, 29, 107111.

FLEMING, N. (2007), VARK: A Guide to Learning Styles (online), (erişim adresi: http:// www.vark-learn.com/english/page.Asp? p=questionnaire), (erişim tarihi: 12 March 2014].

FLEMING, N.D., \& Mills, C. (1992). Not Another Inventory, Rather a Catalyst for Reflection. To Improve Acad, 11, 137-155.

JOHNSON, M. (2009). Evaluation of Learning Style for First Year Medical Students. International Journal for the Scholarship of Teaching and Learning, 3(1), 1-5.

KHARB, P., Samanta, P.P., Jindal, M., Singh, V. (2013). The Learning Styles and the Preferred Teaching-learning Strategies of First Year Medical Students. Journal of Clinical and Diagnostic Research, 7(6), 1089-1092.

LUJAN, L.H., \& Dicarlo, S.E. (2006). Too Much Teaching, Not Enough Learning: What Is The Solution? Adv Physiol Educ, 30, 17-22.

NUZHAT, A., Salem, R.O., Mohammed, S.A., Nasir, A.H. (2011). Learning Style Preferences of Medical Students: A Single-Institute Experience From Saudi Arabia. Int $J$ Med Edu, 2, 70-73.

OKUR, M., Bahar, H.H., Akgun, L., Bekdemir, M. (2011). Department of Mathematics Students' Learning Styles, States of Trait Anxiety and Academic Success. Journal of Turkey Social Research, 15 (3), 123-134.

SHAH, C., Joshi, N., Mehta, H.B., Gokhle, P.A. (2011). Learning Styles Adopted By 
Medical Students. IJRP, 227-229.

TUYSUZ, C., \& Tatar, E. (2008). Effect of the Pre-service Teachers' Learning Styles on Chemistry Achievement and Attitudes. Journal of Mustafa Kemal University Social Science Institution, 5(9), 97-101.

GRAPHICS

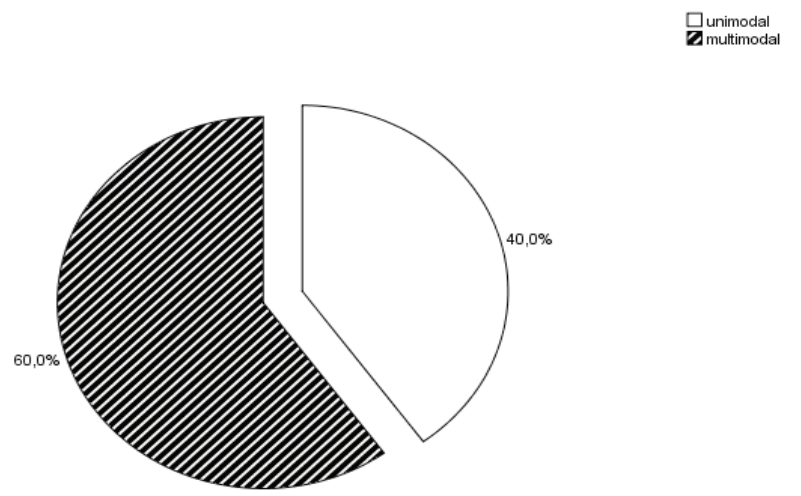

Graphic 1.Learning styles in university students
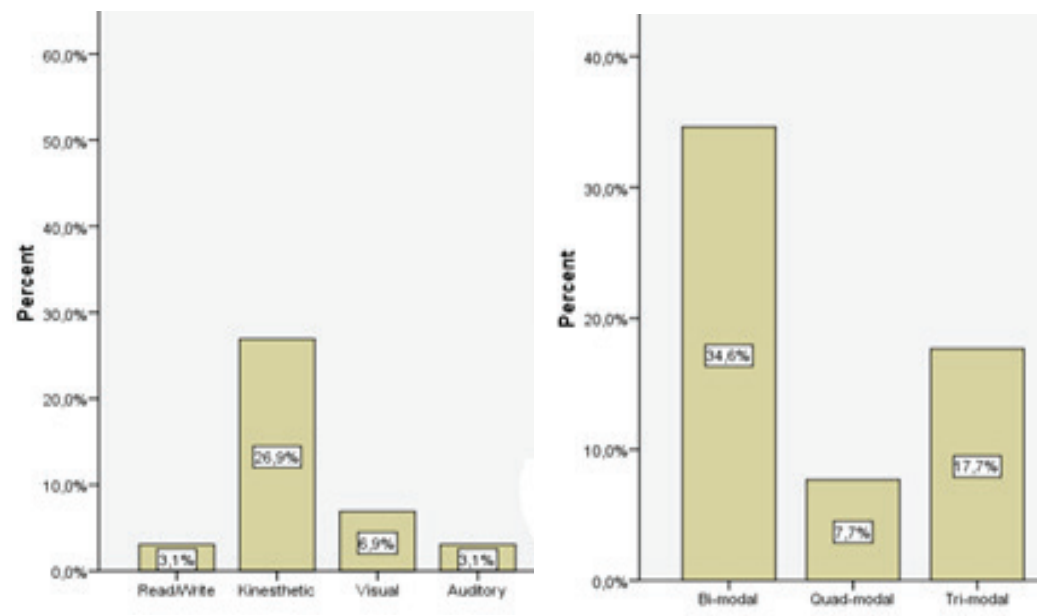

Graphic 2. Unimodal and multimodal learning styles in university students 
TABLES

Table 1. Some features of university students according to their learning styles

\begin{tabular}{|c|c|c|c|c|c|c|}
\hline \multirow{2}{*}{ Features } & \multicolumn{6}{|c|}{ Learning styles } \\
\hline & $\mathbf{v}$ & $\mathbf{A}$ & $\mathbf{K}$ & $\mathbf{R}-\mathbf{W}$ & $\mathbf{M}$ & $x^{2} / p$ \\
\hline \multicolumn{7}{|l|}{ Age (yrs) } \\
\hline$\pm \mathrm{SD}$ & $20.6 \pm 1.2$ & $\begin{array}{c}19.3 \pm \\
0.50\end{array}$ & $\begin{array}{c}20.4 \pm \\
1.1\end{array}$ & $21.0 \pm 1.8$ & $\begin{array}{c}20.9 \pm \\
1.9\end{array}$ & \multirow[t]{2}{*}{$\begin{array}{c}5.442 \\
>0.05 \square\end{array}$} \\
\hline Median & 21 & 19 & 20 & 21 & 21 & \\
\hline \multicolumn{7}{|l|}{ Gender \% (n) } \\
\hline Women & $9.9(\mathrm{n}=9)$ & $4.4(n=4)$ & $\begin{array}{c}27.5 \\
(n=25)\end{array}$ & $4.4(n=4)$ & $\begin{array}{c}53.8 \\
(n=49)\end{array}$ & \multirow[t]{2}{*}{$\begin{array}{c}9.234 \\
>0.05 \dagger\end{array}$} \\
\hline Men & - & - & $\begin{array}{c}25.6 \\
(n=10)\end{array}$ & - & $\begin{array}{c}74.4 \\
(n=29)\end{array}$ & \\
\hline \multicolumn{7}{|l|}{ Class \% (n) } \\
\hline Second class & $6.8(n=5)$ & $5.4(n=4)$ & $\begin{array}{c}33.8 \\
(n=25)\end{array}$ & $\begin{array}{c}4.1 \\
(n=3)\end{array}$ & $\begin{array}{c}50.0 \\
(n=37)\end{array}$ & \multirow[t]{3}{*}{$\begin{array}{c}9.433 \\
>0.05 \dagger\end{array}$} \\
\hline Last class & $7.1(n=4)$ & - & $\begin{array}{c}17.9 \\
(n=10)\end{array}$ & $1.8(\mathrm{n}=1)$ & $\begin{array}{c}73.2 \\
(n=41)\end{array}$ & \\
\hline $\begin{array}{l}\text { Not home } \\
\text { (dormitory, } \\
\text { pension }\end{array}$ & $6.6(n=4)$ & $6.6(n=4)$ & $\begin{array}{c}29.5 \\
(n=18)\end{array}$ & $\begin{array}{c}3.3 \\
(n=2)\end{array}$ & $\begin{array}{c}54.1 \\
(n=33)\end{array}$ & \\
\hline \multicolumn{7}{|l|}{$\begin{array}{l}\text { Academic } \\
\text { achievement } \\
\text { means }\end{array}$} \\
\hline$\pm \mathrm{SD}$ & $2.59 \pm 0.53$ & $\begin{array}{c}2.58 \pm \\
0.54\end{array}$ & $2.56 \pm 0.54$ & $\begin{array}{c}2.59 \pm \\
0.55\end{array}$ & $2.65 \pm 0.49$ & \multirow[t]{2}{*}{$\begin{array}{c}5.217 \\
>0.05^{*}\end{array}$} \\
\hline Median & 2.52 & 2.52 & 2.52 & 2.52 & 2.56 & \\
\hline
\end{tabular}

V: Visual; A: Auditory; K: Kinesthetic; R-W: Read - Write; M: Multimodal

*Kruskal Wallis $\dagger$ Chi-square

Table 2. Methods to obtain information according to the learning styles in university students

\begin{tabular}{|c|c|c|c|c|c|c|}
\hline \multirow{2}{*}{$\begin{array}{l}\text { Methods } \\
\text { to obtain } \\
\text { information }\end{array}$} & \multicolumn{6}{|c|}{ Learning styles } \\
\hline & $\begin{array}{c}\mathbf{V} \\
\%(\mathbf{n})\end{array}$ & $\begin{array}{c}\mathbf{A} \\
\% \\
\text { (n) }\end{array}$ & $\begin{array}{l}\mathbf{K} \\
\% \\
\text { (n) }\end{array}$ & $\begin{array}{c}\text { R-W } \\
\% \\
\text { (n) }\end{array}$ & $\begin{array}{l}\text { M } \\
\% \\
\text { (n) }\end{array}$ & $x^{2} / p$ \\
\hline \multicolumn{7}{|c|}{ Self- lecture notes } \\
\hline Using & $7.6(9)$ & $\begin{array}{l}3.4 \\
(4)\end{array}$ & $\begin{array}{l}27.7 \\
(33) \\
\end{array}$ & $\begin{array}{l}3.4 \\
(4)\end{array}$ & $\begin{array}{l}58.0 \\
(69) \\
\end{array}$ & \multirow[t]{2}{*}{$\begin{array}{l}2.866 \\
0.581\end{array}$} \\
\hline Not using & - & - & $18.2(2)$ & - & $\begin{array}{c}81.8 \\
(9)\end{array}$ & \\
\hline
\end{tabular}


Relation Between Learning Stlyes, Methods for Obtaining Information and Academic Achievements of Turkish University Student

\begin{tabular}{|c|c|c|c|c|c|c|}
\hline Using & $1.5(1)$ & $\begin{array}{l}2.9 \\
(2)\end{array}$ & $\begin{array}{l}33.8 \\
(23)\end{array}$ & $\begin{array}{l}1.5 \\
(1)\end{array}$ & $\begin{array}{l}60.3 \\
(41)\end{array}$ & \multirow[t]{2}{*}{$\begin{array}{l}9.851 \\
\mathbf{0 . 0 4 3}\end{array}$} \\
\hline Not using & $12.9(8)$ & $\begin{array}{l}3.2 \\
(2)\end{array}$ & $12.9(8)$ & $\begin{array}{l}4.8 \\
(3)\end{array}$ & $\begin{array}{l}59.7 \\
(37)\end{array}$ & \\
\hline \multicolumn{7}{|c|}{$\begin{array}{l}\text { Using books and literatures } \\
\text { only in Turkish }\end{array}$} \\
\hline Using & $\begin{array}{l}11.8 \\
(8)\end{array}$ & $\begin{array}{l}5.9 \\
(4)\end{array}$ & $\begin{array}{l}26.5 \\
(18)\end{array}$ & $\begin{array}{l}5.9 \\
(4)\end{array}$ & $\begin{array}{l}50.0 \\
(34)\end{array}$ & \multirow[t]{2}{*}{$\begin{array}{l}14.509 \\
\mathbf{0 . 0 0 6}\end{array}$} \\
\hline Not using & $1.6(1)$ & - & $\begin{array}{l}27.4 \\
(17)\end{array}$ & - & $\begin{array}{l}71.0 \\
(44)\end{array}$ & \\
\hline \multicolumn{7}{|c|}{$\begin{array}{l}\text { Web sites and } \\
\text { pages }\end{array}$} \\
\hline Using & $9.4(6)$ & $\begin{array}{l}3.1 \\
(2)\end{array}$ & $\begin{array}{l}21.9 \\
(14)\end{array}$ & $\begin{array}{l}1.6 \\
(1)\end{array}$ & $\begin{array}{l}64.1 \\
(41)\end{array}$ & \multirow[t]{2}{*}{$\begin{array}{l}3.575 \\
0.467\end{array}$} \\
\hline Not using & $4.5(3)$ & $\begin{array}{l}3.0 \\
(2)\end{array}$ & $\begin{array}{l}31.8 \\
(21)\end{array}$ & $\begin{array}{l}4.5 \\
(3)\end{array}$ & $\begin{array}{l}56.2 \\
(37)\end{array}$ & \\
\hline \multicolumn{7}{|c|}{$\begin{array}{l}\text { Questions asked } \\
\text { in past years }\end{array}$} \\
\hline Using & $4.1(3)$ & $\begin{array}{l}2.7 \\
(2)\end{array}$ & $\begin{array}{l}27.0 \\
(20)\end{array}$ & $\begin{array}{l}2.7 \\
(2)\end{array}$ & $\begin{array}{l}63.5 \\
(47)\end{array}$ & \multirow[t]{2}{*}{$\begin{array}{l}2.553 \\
0.635\end{array}$} \\
\hline Not using & $\begin{array}{c}10.7 \\
(6)\end{array}$ & $\begin{array}{l}3.6 \\
(2)\end{array}$ & $\begin{array}{l}26.8 \\
(15)\end{array}$ & $\begin{array}{l}3.6 \\
(2)\end{array}$ & $\begin{array}{l}55.4 \\
(31)\end{array}$ & \\
\hline
\end{tabular}

V: Visual; A: Auditory; K: Kinesthetic; R-W: Read -Write; M: Multimodal 